Volume 11

Issue 1 Information and Communications

Technologies in Mass Atrocities Research and

Article 7

Response

$5-2017$

\title{
Sensors Everywhere: Using Satellites and Mobile Phones to Reduce Information Uncertainty in Human Rights Crisis Research
}

Christoph Koettl

Amnesty International

Follow this and additional works at: https://digitalcommons.usf.edu/gsp

\section{Recommended Citation}

Koettl, Christoph (2017) "Sensors Everywhere: Using Satellites and Mobile Phones to Reduce Information Uncertainty in Human Rights Crisis Research," Genocide Studies and Prevention: An International Journal: Vol. 11: Iss. 1: 36-54.

DOI:

http://doi.org/10.5038/1911-9933.11.1.1440

Available at: https://digitalcommons.usf.edu/gsp/vol11/iss1/7

This Symposium on the State of the Field is brought to you for free and open access by the Open Access Journals at Digital Commons @ University of South Florida. It has been accepted for inclusion in Genocide Studies and Prevention: An International Journal by an authorized editor of Digital Commons @ University of South Florida. For more information, please contact digitalcommons@usf.edu. 
Sensors Everywhere: Using Satellites and Mobile Phones to Reduce Information Uncertainty in Human Rights Crisis Research

\section{Acknowledgements}

The views expressed are solely those of the author, and do not necessarily reflect the positions of Amnesty International. 


\title{
Sensors Everywhere: Using Satellites and Mobile Phones to Reduce Information Uncertainty in Human Rights Crisis Research
}

\author{
Christoph Koettl \\ Amnesty International \\ Washington, D.C., USA
}

\begin{abstract}
Introduction
Human rights researchers pin much hope on the use of information and communication technologies (ICTs) to strengthen the quality of their research. Increased trainings, ${ }^{1}$ funding, ${ }^{2}$ and hiring of specialized staff are all signs of the high expectations that technology will positively impact, if not provide an easy fix, to current human rights problems. However, in order to realize the actual potential of ICTs, it is important to conceptualize clearer their added value, and to go beyond wishful assumptions: A single app or interactive map will hardly catch a war criminal, ${ }^{3}$ and ICTs are no panacea for atrocity detection or response.

ICTs by themselves do not deliver complete truth - let alone provide a shortcut to justice - as they largely capture a limited scope of information. Instead, they add very specific details and insights to research. Their significant added value in mass atrocities research thus arises from their ability to reduce information uncertainty. A 2015 UN report on ICTs and human rights, specifically in regards to the right to life, pointedly captures the challenge ICTs can help to address:
\end{abstract}

(...) the work relating to protecting this right [to life] often concerns disputed facts or even the availability of facts. Individuals commit violations of the right to life not because they believe it is justifiable, but because they believe they will not be called on to justify themselves. That places a premium on fact-finding and evidence. ${ }^{4}$

Uncertainty can best be described as the inability to assign probabilities. Information uncertainty in a human rights documentation context, as stated in the quote above, encompasses two related challenges: information scarcity and the unknown quality of available information. While these are not new challenges in human rights research, the latter is exacerbated in the digital age.

This article describes how ICTs reduce information uncertainty during human rights crises, which, by definition, are characterized by a high degree of uncertainty and the commission of atrocity crimes. The author will showcase how ICTs are integrated into human rights crisis research to detect and document mass atrocities, i.e. crimes under international law such as war crimes, crimes against humanity, or genocide. It is written from a practitioner's perspective, drawing from the work of a global human rights watchdog, thus avoiding the trap of inferring conclusions from a single region or a specific tool. Having said that, since ICTs describe a wide range of technologies that enable the electronic collection, transmission, presentation or storage of data, this article focuses on two specific types of ICTs that are used to address information uncertainty: geospatial and mobile phone technologies.

\section{Crisis, Uncertainty and the "Lemon Problem"}

Information uncertainty is especially high during times of crisis. Common traits of human rights crises are condensed in the following table:

\footnotetext{
${ }^{1}$ See, for example, "Remote Sensing for Humanitarian Programs Workshops," Harvard Humanitarian Initiative, accessed July 20, 2016, http://hhi.harvard.edu/education/workshops/remote-sensing.

${ }^{2}$ See, for example, “The Tech Challenge for Atrocity Prevention," Humanity United, accessed July 20, 2016, http:// thetechchallenge.org/blog/.

${ }^{3}$ Owen Bowcott, "eyeWitness to Atrocities: The App Aimed at Bringing War Criminals to Justice," The Guardian, June 7, 2015, accessed July 25, 2016, https://www.theguardian.com/technology/2015/jun/08/eyewitness-to-atrocities-the-appaimed-at-bringing-war-criminals-to-justice; Christoph Koettl, “\#DemandJustice: The Website War Criminals Don't Want You To Share," July 19, 2012, accessed July 25, 2016, http://blog.amnestyusa.org/africa/demandjustice-thewebsite-war-criminals-dont-want-you-to-share/.

${ }^{4}$ United Nations, Report of the Special Rapporteur on extrajudicial, summary or arbitrary executions, Christof Heyns: Use of information and communications technologies to secure the right to life, April 24, 2015 (A/HRC/29/37), 5-6. Highlighting by author.
}

Christoph Koettl, "Sensors Everywhere: Using Satellites and Mobile Phones to Reduce Information Uncertainty in Human Rights Crisis Research" Genocide Studies and Prevention 11, 1 (2017): 36-54. @2016 Genocide Studies and Prevention. 


\begin{tabular}{|c|c|c|}
\hline Issue & Description & $\begin{array}{l}\text { Examples \& Human } \\
\text { Rights Concerns }\end{array}$ \\
\hline $\begin{array}{l}\text { Lack of physical } \\
\text { access }\end{array}$ & $\begin{array}{l}\text { This presents a major challenge for a } \\
\text { profession that is centered on field based } \\
\text { fact-finding and interviewing witnesses. } \\
\text { Modern communication technologies } \\
\text { allow for the continuation of a testimony- } \\
\text { centered approach, as witnesses can be } \\
\text { interviewed remotely. However, direct } \\
\text { access is still considered the gold standard } \\
\text { in human rights research, which is } \\
\text { challenged when confronted with major } \\
\text { human rights crises that make access } \\
\text { almost impossible. }\end{array}$ & $\begin{array}{l}\text { North Korea } \\
\text { - Crimes against } \\
\text { humanity } \\
\text { Darfur } \\
\text { - War crimes } \\
\text { - Crimes against } \\
\text { - humanity } \\
\text { - Genocide }\end{array}$ \\
\hline $\begin{array}{l}\text { Information } \\
\text { scarcity }\end{array}$ & $\begin{array}{l}\text { Situations that are impacted by armed } \\
\text { conflict and other factors that lead to a } \\
\text { sharp decline in human security are often } \\
\text { characterized by a lack of information, } \\
\text { which make human rights fact-finding } \\
\text { difficult or impossible. Perpetrators have } \\
\text { some control over information flows by } \\
\text { limiting freedom of expression through } \\
\text { censorship, surveillance or the outright } \\
\text { destruction of telecommunications } \\
\text { infrastructure. }\end{array}$ & $\begin{array}{l}\text { Boko Haram affected } \\
\text { areas } \\
\text { - War crimes } \\
\text { - Crimes against } \\
\text { humanity }\end{array}$ \\
\hline $\begin{array}{l}\text { Information } \\
\text { overload }\end{array}$ & $\begin{array}{l}\text { While in exact contrast to the previous } \\
\text { point, human rights crises can also see a } \\
\text { challenge of too much information, } \\
\text { leading to problems around information } \\
\text { triage and quality control. Considering the } \\
\text { increase in cell-phone and internet } \\
\text { penetration globally, the information } \\
\text { ecosystem as seen in the Syrian conflict is } \\
\text { likely to become the norm during future } \\
\text { human rights crises. A report on a } 2012 \\
\text { workshop on using scientific evidence at } \\
\text { the International Criminal Report labeled } \\
\text { this challenge as the "coming storm" of } \\
\text { potential evidence }\end{array}$ & $\begin{array}{l}\text { Syria } \\
\text { - Crimes against } \\
\text { humanity } \\
\text { - War crimes }\end{array}$ \\
\hline
\end{tabular}

Table 1. Common traits of human rights crises.

A cross-cutting attribute across these issues is the presence of serious, often widespread, human rights violations. Crisis situations are prone to the commission of atrocity crimes, resulting from perpetrator expectations that their crimes will go unnoticed or can be easily dismissed or minimized $^{5}$ in an environment of high information uncertainty.

${ }^{5}$ Scott Edwards, "Fieldwork from the Sky: Remote Data Collection from War Zones," International Sudan Studies Association 2009 annual conference in Pretoria (2009), South Africa, 1-3. 
The Lemon Problem

The combination of the characteristics listed in Table 1 create what can be referred to as the "lemon problem" - the risk of using misinformation that can discredit an entire research project. While this is an old challenge, it has been exacerbated in the digital age, where the spread of misinformation is made easier by digital social media networks. ${ }^{6}$

The lemon analogy is borrowed from economics. The term lemon is used in the United States to describe a defective car, and was used by Nobel Prize winning economist George Akerlof to analyze quality uncertainty, using the example of a car buyer who faces the risk of buying a bad $\operatorname{car}^{7}$ (whereas a used-car dealer represents an institution that reduces quality uncertainty). International theorist Robert Keohane used this analysis to explain the creation of institutions in international affairs. ${ }^{8}$

Both of these concepts prove useful in assessing the value of ICTs for human rights crisis research. In this context, a lemon describes a piece of misinformation - or bad information - that creates the danger of discrediting the accuracy of research. Accuracy has always been at the core of human rights fact-finding, as standard works on this topic emphasize:

For NGOs, the stakes in surviving (...) scrutiny could not be higher. The credibility of their fact-finding is their stock-in-trade. Broadly stated, the chief objective of human rights NGOs is to promote compliance with international human rights standards. (...) Fact-finding lies at the heart of these efforts, and the fact-finding 'works' when it convinces the target audience that the published allegations are well founded. ${ }^{9}$

The opportunities for human rights documentation stemming from the omnipresence of digital sensors are undeniable. Investigations by both intergovernmental ${ }^{10}$ and non-governmental ${ }^{11}$ human rights monitoring groups increasingly rely on video or photographic evidence. However, the rise of ICTs and citizen media leads to an exponentially growing lemon problem. With lower

${ }^{6}$ For a recent study on the online misinformation ecosystem see Craig Silverman, "Lies, Damn Lies, and Viral Content. How news websites spread (and debunk) online rumors, unverified claims, and misinformation," Tow Center for Digital Journalism, February 10, 2015. As the author states on page 35: "There is a growing online misinformation ecosystem that churns out false information at an increasing pace. Its success often depends on two factors: the ability to cause sharing cascades on social networks and the ability to get online media to assist in the propagation, thereby adding a layer of credibility that further increases traffic and sharing."

${ }^{7}$ George Akerlof, “The Market for 'Lemons': Quality Uncertainty and the Market Mechanism,” The Quarterly Journal of Economics 84, 3 (Aug 1970), 488-500.

${ }^{8}$ Robert O. Keohane, After Hegemony: Cooperation and Discord in the World Political Economy (Princeton: Princeton University Press, 1984). See also a 2004 interview with Keohane: "Akerlof showed how in an economic market, the used-car market, there could be market failure. That is, the lack of institutions could create a situation where prices didn't clear. A buyer was not able to buy a car from a seller for a mutually agreed price which would have been good for them both, because there were no institutions, there was nobody to make credible promises unless you have this institution of the used-car dealer. I saw immediately that the used-car dealer was very much like the international institution, which would increase the credibility, the promises, reduce uncertainty, and reduce the cost of transactions, and, therefore, this was the key to thinking about the role of international institutions." "Robert Keohane Interview: Conversations with History", Institute of International Studies, University of California Berkeley, March 9, 2004, accessed July 27, 2016, http://globetrotter.berkeley.edu/people4/Keohane/keohane-con2.html.

${ }^{9}$ Diane Orentlicher, "Bearing Witness: The Art and Science of Human Rights Fact-finding," Harvard Human Rights Journal 3 (1990), 92-93.

${ }^{10}$ On the use of information and communications technologies by human rights mechanisms, see United Nations, "Report of the Special Rapporteur", 17-19. For a specific example, see also: Office of the UN High Commissioner for Human Rights, United Nations, Technical Note prepared by the Special Rapporteur on extrajudicial, summary or arbitrary executions, Mr. Philip Alston, in relation to the authenticity of the "Channel 4 videotape," January 7, 2010, accessed July 27, 2016, http:// groundviews.org/wp-content/uploads/2011/05/un technical note.pdf?x98647.

${ }^{11}$ See, for example, Human Rights Watch, "Sri Lanka: Execution Video Shows Need for International Inquiry," August 26, 2009, accessed July 25, 2016, http://www.hrw.org/news/2009/08/26/sri-lanka-execution-video-shows-needinternational-inquiry; Amnesty International, “'Shocking' Video Shows Armed Group Carrying Out Summary Killings of Men in Syria's Idlib Province, Says Amnesty International," November 1, 2012, accessed July 25, 2016, http://www.amnestyusa.org/news/press-releases/shocking-video-shows-armed-group-carrying-out-summarykillings-of-men-in-syria-s-idlib-province-says. 
barriers to self-publishing and re-sharing digital content instantly and globally, the spread of misinformation increases. The lack of institutions that provide quality control-such as traditional media outlets before the advent of digital social networks - contribute to this challenge, which only recently came under scrutiny through the fake news debate following the 2016 U.S. presidential elections. The human rights profession is not immune to this problem, and examples of human rights related lemons are plentiful:

- In a since removed tweet, Human Rights Watch Executive Director Ken Roth used a drone video from the destruction in Gaza in the aftermath of the 2014 conflict to describe the impact of barrel bombs on Aleppo.

- In the first half of 2016, images from the conflict in north-east Nigeria were repeatedly used to support claims of mass atrocities in other countries. The same images were then used in the context of extrajudicial executions in Burundi, and the crisis in South Sudan starting in June $2016 .^{12}$

- A video showing extreme violence, likely stemming from Kenya, is repeatedly circulated online. The highly graphic video was used to describe post-election violence in Cote $\mathrm{D}^{\prime}$ Ivoire, ${ }^{13}$ in addition to describing violations in the context of South Sudan and Burma.

- The BBC used an image from Iraq in 2003 for a story on the Houla massacre in Syria in May 2012. ${ }^{14}$

- In the last week of May 2016, a video of a killing was posted, reportedly related to the Fallujah Offensive that started in late May. ${ }^{15}$ However, a second video ${ }^{16}$ of the same incident was already shared in mid-April 2016. The incident was thus old and not related to this specific military operation.

This list is a non-comprehensive sample. Global human rights groups are faced with such digital misinformation on a weekly basis. There is another cost of the lemon problem, in addition to the high risk of inaccuracy. It forces human rights researchers to treat every piece of digital content with extreme caution, and creates high opportunity costs to review and assess a video or image. There is no silver bullet to detect lemons, and the verification process of a single piece of digital content can easily take up an entire day. ${ }^{17}$ Consequently, a lot of content is either ignored (the triage problem) or added on only as an afterthought, once enough traditional research is gathered.

Corporate institutions emerged over the last years to fill the void in quality control, the most prominent being Storyful, the self-described world's first "news agency (...) for the social media age."18 However, with its focus on viral and newsworthy content and its cost-prohibitive subscription, this is not a suitable option for human rights groups, thus leaving it to individual researchers themselves to verify information. Both large news organizations and human rights organizations started to set up internal institutions to provide quality control, such as the BBC's

\footnotetext{
${ }^{12}$ Andrea Spada, Twitter Post, March 1, 2016, 6:43a.m, https://twitter.com/Baldoriano/status/704633182063370240. [Warning: Graphic Content]

${ }^{13}$ Julien Pain, “Beware of Internet Misinformation: Hoax Footage of Atrocities in Ivory Coast," France 24, July 4, 2011, accessed July 27, 2016, http://observers.france24.com/en/20110407-beware-internet-misinformation-hoax-footageatrocities-ivory-coast.

${ }^{14}$ Chris Hamilton, “Houla Massacre Picture Mistake," BBC, May 29 2012, accessed July 25, 2016, http://www.bbc.co.uk/ blogs/theeditors/2012/05/houla massacre picture mistake.html.

${ }^{15}$ Video originally posted on Twitter https://twitter.com/irakiRevolution/status/736240104155586561. Account has been deleted.

${ }^{16}$ Twitter Post, April 22, 2016, 10:27p.m. https://twitter.com/D yassir 1/status/723699727146057728. [Warning: Graphic Content]

${ }^{17}$ Christoph Koettl, "Citizen Media Research and Verification: An Analytical Framework for Human Rights Practitioners," (Human Rights in the Digital Age: CGHR Practitioner Paper 1, Cambridge, UK: University of Cambridge Centre of Governance and Human Rights), January 2016, accessed July 27, 2016, http://www.cghr.polis.cam.ac.uk/publications/ cghr-practitioner-papers-series/paper-1.

${ }^{18}$ Mark Little, “The Human Algorithm," May 20, 2011, accessed July 27, 2016, http://blog.storyful.com/2011/05/20/thehuman-algorithm-2.
} 
user-generated content hub, ${ }^{19}$ or Amnesty International's Tactical Research and Analysis Team. ${ }^{20}$ An interesting trend to follow will be the creation of collaborative and volunteer networks to address the lemon problem, such as Amnesty International's Digital Verification Corps, ${ }^{21}$ which is tasked "to find content in social media streams and to verify videos and photographs to help (...) researchers monitor and report on human rights violations."22 Journalism schools started to offer graduate program in so-called Social Journalism that include coursework on verification, ${ }^{23}$ and the human rights field might follow suit.

A technical solution to address the lemon problem is documentation apps that capture relevant metadata and chain of custody records. These have the potential to be impactful on specific issues and when working with dedicated networks - as Karen Naimer, Widney Brown, and Ranit Mishori write in their article published in this special issue of Genocide Studies and Prevention-but are less likely to be adapted by large numbers of people or utilized by bystanders. ${ }^{24}$

\section{Applications in Human Rights Crisis Research}

ICTs can help address the challenges faced during crises as listed in Table 1. Geospatial technologies and camera enabled cell phones have proven the most useful in human rights crisis research, as they can be used to circumvent access restrictions to collect and transfer potential evidence.

Geospatial technologies, most notably satellite imagery, are some of the most impactful tools to circumvent access restrictions and address the information scarcity problem. As one of the case studies below will detail, satellite imagery enables human rights fact-finding in inaccessible areas such as North Korea. While satellite images are limited regarding the human rights issues they can document, this technology has proven successful to document a range of violations, including violations of International Humanitarian Law (IHL) and Economic, Social and Cultural Rights (ESCR). It is important to note that space-based remote sensing allows for the detection of both spatial and temporal trends. Vast archives of satellite imagery give researchers access to historical records, which can be highly relevant in the documentation of atrocity crimes. Relevant features to assess include: civilian, military or humanitarian infrastructure, and if and how they have changed over time. ${ }^{25}$ Further, satellite sensors collect data across the infrared, visible, and ultraviolet wavelength of the electromagnetic spectrum. This has ramifications for human rights researchers, as it allows going beyond simple visual analysis (e.g. housing demolitions or other infrastructure demolitions) to more advanced analysis, such as detecting petrochemical releases $^{26}$ or thermal anomalies. ${ }^{27}$ Remote sensing technologies will gain in importance over the coming years, as more commercial actors enter the sub-meter resolution market, including micro-satellite companies, and entry barriers to using unmanned aerial vehicles (UAVs) get lower.

\footnotetext{
${ }^{19}$ Sally Taft, "How Did You Help Us Change the Way We Report the News?" December 27, 2014, accessed July 28, 2016, http://www.bbc.com/news/world-30421631.

${ }^{20}$ See the informal blog of the team, "Lemming Cliff - View from the Event Horizon," accessed March 1, 2017, https:// medium.com/lemming-cliff.

${ }^{21}$ PBS Newshour, "A New Generation of Human Rights Investigators Turns to High-tech Methods," February 13, 2017, accessed February 27, 2017, https://www.youtube.com/watch?v=dDLtL8aWRAQ.

${ }^{22}$ Sam Dubberley, “New Data and the Importance of Collaboration," July 18, 2016, accessed July 28, 2016, https:// citizenevidence.org/2016/07/18/new-data-and-the-importance-of-collaboration/.

${ }^{23}$ The City University of New York, Graduate School of Journalism, accessed July 25, 2016, https://www.journalism.cuny. edu/academics/social-journalism/curriculum-and-courses/.

${ }^{24}$ Karen Naimer, Widney Brown and Ranit Mishori, "MediCapt in the Democratic Republic of the Congo: The Design, Development, and Deployment of Mobile Technology to Document Forensic Evidence of Sexual Violence," Genocide Studies and Prevention: An International Journal 11, no. 1 (2017): 25-35.

${ }^{25}$ See, in detail, Nathaniel A. Raymond, Brittany L. Card, and Isaac L. Baker, "A New Forensics: Developing Standard Remote Sensing Methodologies to Detect and Document Mass Atrocities," Genocide Studies and Prevention: An International Journal, Volume 8, Issue 3, (2013) Article 6.

${ }^{26}$ American Association for the Advancement of Science, "Documentation of Petrochemical Release: Bodo, Nigeria," accessed July 26, 2016, http://www.aaas.org/page/documentation-petrochemical-release-bodo-nigeria.

${ }^{27}$ Lars Bromley, "Relating Violence to MODIS Fire Detections in Darfur, Sudan," International Journal of Remote Sensing, 31, 9 (2010), 2277-2202.
} 
Mobile phone technology has implications for gaining access to information and has led to an explosion in open source information that human rights researchers can exploit. Open source information includes publically accessible information such as news articles, academic articles, statistics, and, increasingly, audiovisual content or reporting shared through online social networks. This rapid growth of information is fed by smart phone technology and enabled by digital networks. It is important to note that the audiovisual content by itself is nothing new. Prominent human rights-relevant examples from the pre-digital age are the Rodney King video or the Zoran Petrovic video of Srebrenica. ${ }^{28}$ Camera enabled cell phones, the digitization of content, and the ongoing increase in internet penetration are the game changers. The result is that information is distributed less through official media outlets, such as TV broadcasts and newspapers, and more through online social networks in real-time. Thus, more than ever, reporting on human rights abuses moves beyond the control of governments. The implications for researchers are profound, similar to the advent of commercial remote sensing.

The following case studies and examples provide insights on how these technologies positively impact human rights fact-finding.

\section{Satellite Imagery}

The unspeakable atrocities that are being committed against inmates of the kwanliso political prison camps resemble the horrors of camps that totalitarian States established during the twentieth century. The institutions and officials involved are not held accountable. Impunity reigns. $^{29}$

The value of ICTs to address lack of information is most powerfully demonstrated in the use of satellite imagery to document political prison camps in North Korea. Despite severe constraints, the UN Commission of Inquiry on North Korea was able to document serious violations of international human rights law on a systematic level that suggest that North Korean authorities are committing crimes against humanity. ${ }^{30}$ ICTs played a crucial role in contributing to the establishment of the Commission and the collection of rare evidence used by the Commission.

North Korea is one of the world's most reclusive and inaccessible countries. Human rights researchers face the following problems when attempting to document the system of political prison camps and associated human rights violations:

- Human rights researchers do not have direct access to the country.

- No other independent observers, such as international journalists or the International Committee of the Red Cross (ICRC), ${ }^{31}$ have access to the political prison camps

- Due to heavy restrictions on freedom of expression, there is no online or social media content available of the camps. In fact, there appears to be only a single piece of audiovisual content available of the political camps, which is a video by Japanese Fuji TV, reportedly of Yodok camp. ${ }^{32}$

Human rights researchers thus have only two options to research camp conditions -by interviewing the few people who were in one of the camps and fled the country, or by using remote

\footnotetext{
28 "Rodney King beating video, full length footage," YouTube video, 8:08, March 3, 1991, accessed July 25, 2016, https://www.youtube.com/watch?v=sb1WywIpUtY; "Zoran Petrovic video," YouTube video, 1:16, July 14, 1995, accessed July 25, 2016, https://www.youtube.com/watch?v=344e D-Vc7g.

${ }^{29}$ Office of the High Commissioner for Human Rights, "North Korea: UN Commission documents wide-ranging and ongoing crimes against humanity, urges referral to ICC," February 7, 2014, accessed July 27, 2016, http://www.ohchr. org/EN/NewsEvents/Pages/DisplayNews.aspx?NewsID=14255\&LangID=E\#sthash.ukBW9bLP.dpuf.

${ }^{30}$ Ibid.

${ }^{31}$ While the ICRC has a small presence in Pyongyang, it does not appear to have access to any political prison camps. See ICRC, "The ICRC in the Democratic People's Republic of Korea," accessed July 27, 2016, https://www.icrc.org/en/ document/dprk-icrc-activities-leaflet.

${ }^{32}$ Reuters, Video Shows Harsh Life in N. Korean Camp - Japan TV, February 27, 2004.
} 
sensing. Detention facilities lend themselves very well for remote observation, due to the fact that the detention infrastructure is easy to detect and assess from afar. The rationale of using remote sensing came from addressing some of the following uncertainties:

- The very existence of the camps: North Korean officials deny the existence of political prison camps. While denial is a standard strategy of perpetrators, ${ }^{33}$ in this case it is especially difficult to counter authorities' narrative due to an almost complete lack of information about the camps. The dependence on an extremely limited number of eyewitness becomes even more challenging when testimony appears to contain inaccuracies. ${ }^{34}$

- The number of camps: There was some dispute about the exact number of political prisons camps, due to reports of closures. Current reports estimate four active camps.

- The number of prisoners: It remains unclear how large the size of the prison population is, and current estimates list 80,000-120,000 people. ${ }^{35}$

In 2003, the US Committee on Human Rights North Korea (HRNK) published a seminal report on the camp system. ${ }^{36}$ It was one of the first times a non-governmental organization deployed remote sensing for human rights documentation, providing visual evidence of a vast system of political prison camps. Amnesty International later used satellite to document the existence of the camps, as well as apparent changes to the camps' infrastructure. In 2013, during the run up to the vote at the UN Human Rights Council that established the Commission of Inquiry, Amnesty International released findings that suggest that authorities are expanding its detention infrastructure, by setting up a new security zone adjacent to Camp $14 .{ }^{37}$ This determination was made by analyzing satellite imagery that showed the construction of fences and controlled access points, which limited the freedom of movement of people living within the newly created control zone.

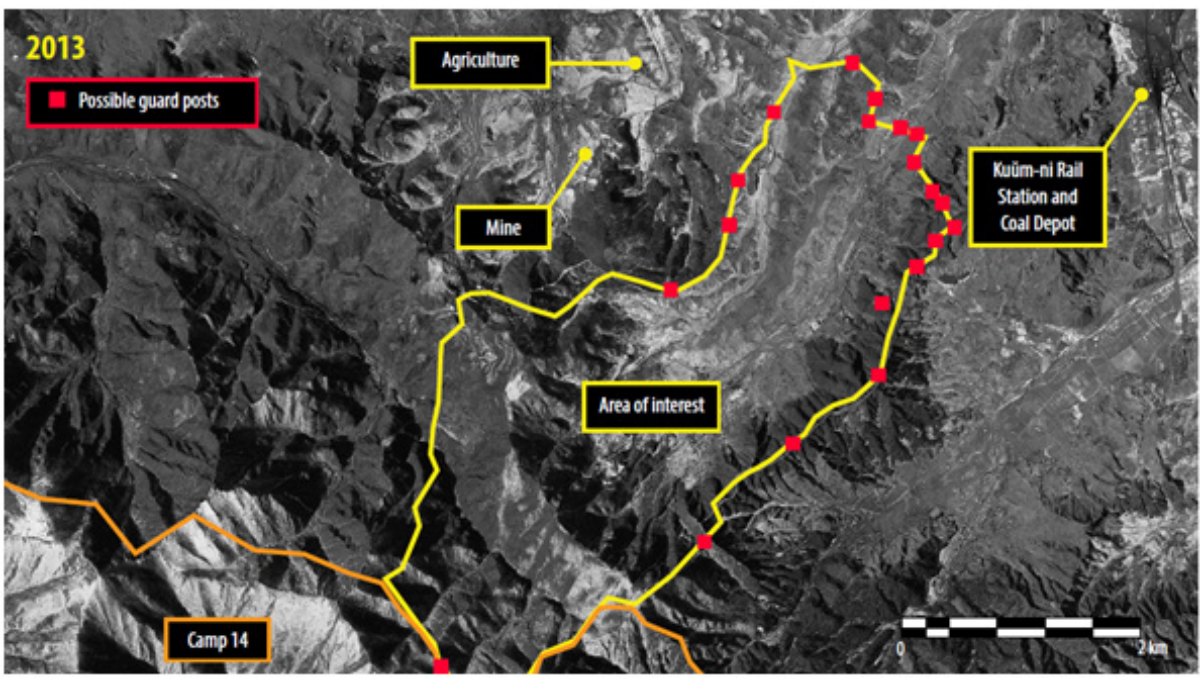

Figure 1. @ DigitalGlobe. February 7, 2013.

\footnotetext{
${ }^{33}$ Edwards, Fieldwork from the Sky, 1-3.

${ }^{34}$ Catherine E. Shoichet and Madison Park, "North Korean Prison Camp Survivor Admits Inaccuracies, author says," CNN, January 20, 2015, accessed July 25, 2016, http://www.cnn.com/2015/01/18/asia/north-korea-defector-changesstoryl.

${ }^{35}$ Office of the High Commissioner for Human Rights, “North Korea: UN Commission Documents Wide-ranging and Ongoing Crimes Against Humanity."

${ }^{36}$ David Hawk, “The Hidden Gulag. Exposing North Korea's Prison Camps. Prisoners' Testimonies and Satellite Photographs," US Committee for Human Rights in North Korea, (2003), accessed July 27, 2016, https://www.hrnk.org/ uploads/pdfs/NKHiddenGulag_DavidHawk.pdf.

${ }^{37}$ Amnesty International, "North Korea: New images show blurring of prison camps and villages," March 7, 2013, accessed July 27, 2016, https://www.amnesty.org/en/latest/news/2013/03/north-korea-new-images-show-blurringprison-camps-and-villages/.
} 
A few months later, new satellite imagery analysis documented ongoing investment in the camps' infrastructure, such as new housing blocks and an expansion of production facilities ${ }^{38}-$ facts that were in direct contrast with ongoing North Korean authorities' claims that the political prison camps do not exist.

Satellite image analysis subsequently played a crucial role in the report of the Commission of Inquiry, the most comprehensive record of the human rights situation in North Korea. The value of the imagery analysis was highlighted by Chairman Michael Kirby during the presentation of the report, and a separate appendix with only satellite images is a further sign of the importance of this content to the investigation..$^{39}$

In addition to documenting the very existence of the camps, thus establishing basic facts in, details were derived from the imagery that addressed some of the other uncertainties. For example, additional analysis from December 2013 determined the exact size of Camp 16, which with $560 \mathrm{~km} 2$ is three times the size of Washington, D.C. ${ }^{40}$ Analysis by the HRNK and AllSource Analysis pointedly captures how satellite imagery reduces information uncertainties in regards to speculations on the creation of a new camp:

The Ch'oma-bong Restricted Area is unique among North Korea's network of [political prison camps] in that its identification as a political detention facility is based upon the analysis of satellite imagery, comparison of its infrastructure characteristics with other [political prison camps] (e.g., security perimeter with entrance and guard positions, internal arrangement, etc.), and its physical association with Camp 14-they share a common security perimeter for approximately 3.1 kilometers. ${ }^{41}$

Looking forward, more could likely be done to gather additional human rights relevant facts: For example, occasionally satellites capture construction in progress, as was the case in a 2013 satellite image of Camp 16. Such insights into the size of houses and rooms could be used to make more precise estimations on the size of the prisoner populations. With the advent of satellite video, ${ }^{42}$ the potential capture of active vehicles and checkpoints could be indications of ongoing activities in the camps, which might counteract claims to the contrary.

The use of satellite images in human rights documentation has become standard since HRNK's 2003 report and too many examples exist to list in this article. However, two additional examples are especially useful to demonstrate how satellite images are reducing information uncertainty.

In January 2015, both Amnesty International and Human Rights Watch released satellite images of one of the deadliest Boko Haram attacks to date. The high-resolution images of the burned down villages of Baga and Dora Baga in north-east Nigeria created massive media coverage, including front page coverage in the New York Times. ${ }^{43}$ It is noteworthy that this coverage came approximately two weeks after the actual attack happened. Only minimal information was available of the attack and no journalists or human rights researchers could reach the affected area. This information challenge was exacerbated by a lack of local communications infrastructure.

In Sri Lanka in 2009, satellite imagery allowed researchers to gain remote access to the conflict affected area and provide human rights relevant documentation, such as the presence of impact craters or the emergence of gravesites in the so-called Civilian Safety Zone. Additionally,

${ }^{38}$ Amnesty International, “New satellite images show scale of North Korea's repressive prison camps," December 5, 2013, accessed July 27, 2016, https://www.amnesty.org/en/latest/news/2013/12/new-satellite-images-show-scale-northkorea-s-repressive-prison-camps/.

${ }^{39}$ Office of the High Commissioner for Human Rights "Satellite images of currently existing political prison camps (kwanliso) in the Democratic People's Republic of Korea," January 28 2014, accessed July 27, 2014, http://www.ohchr. org/EN/HRBodies/HRC/CoIDPRK/Pages/ReportoftheCommissionofInquiryDPRK.aspx.

${ }^{40}$ Amnesty International, New satellite images show scale of North Korea's repressive prison camps.

${ }^{41}$ Joseph S. Bermudez Jr., Andy Dinville, and Mike Eley, “North Korea: Ch'oma-bong Restricted Area,” March 17, 2016, accessed July 27, 2016, https://www.hrnk.org/uploads/pdfs/ASA HRNK Chmbg 201603 FINAL.pdf.

42 "Terra Bella," Google, accessed March 17, 2017, https:/terrabella.google.com/.

43 "Frontpage January 16, 2015," New York Times, accessed July 20, 2016, http://www.nytimes.com/images/2015/01/16/ nytfrontpage/scan.pdf. 


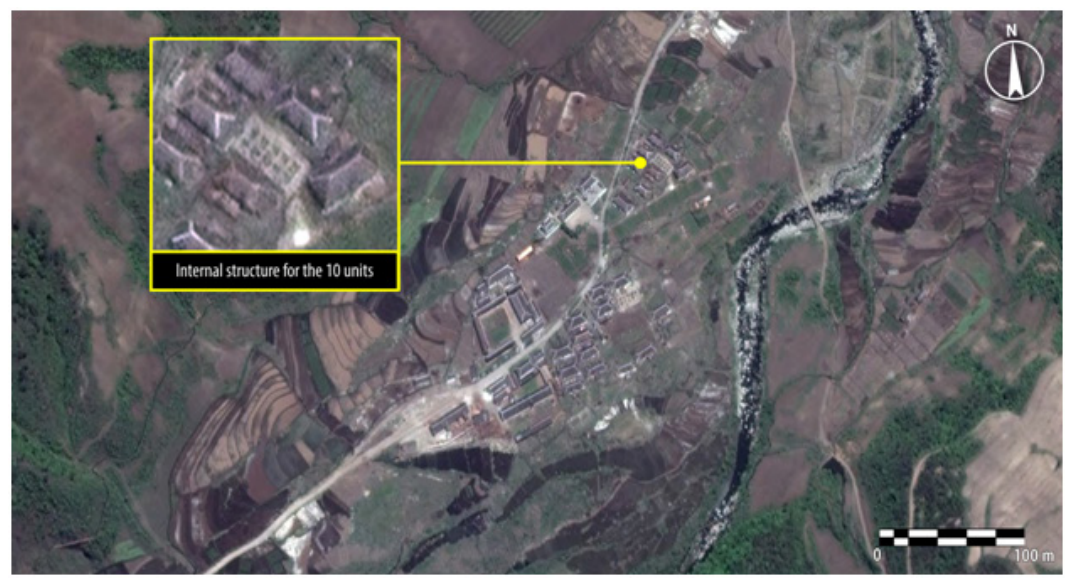

Figure 2. (c) Digital Globe. May 26, 2013.

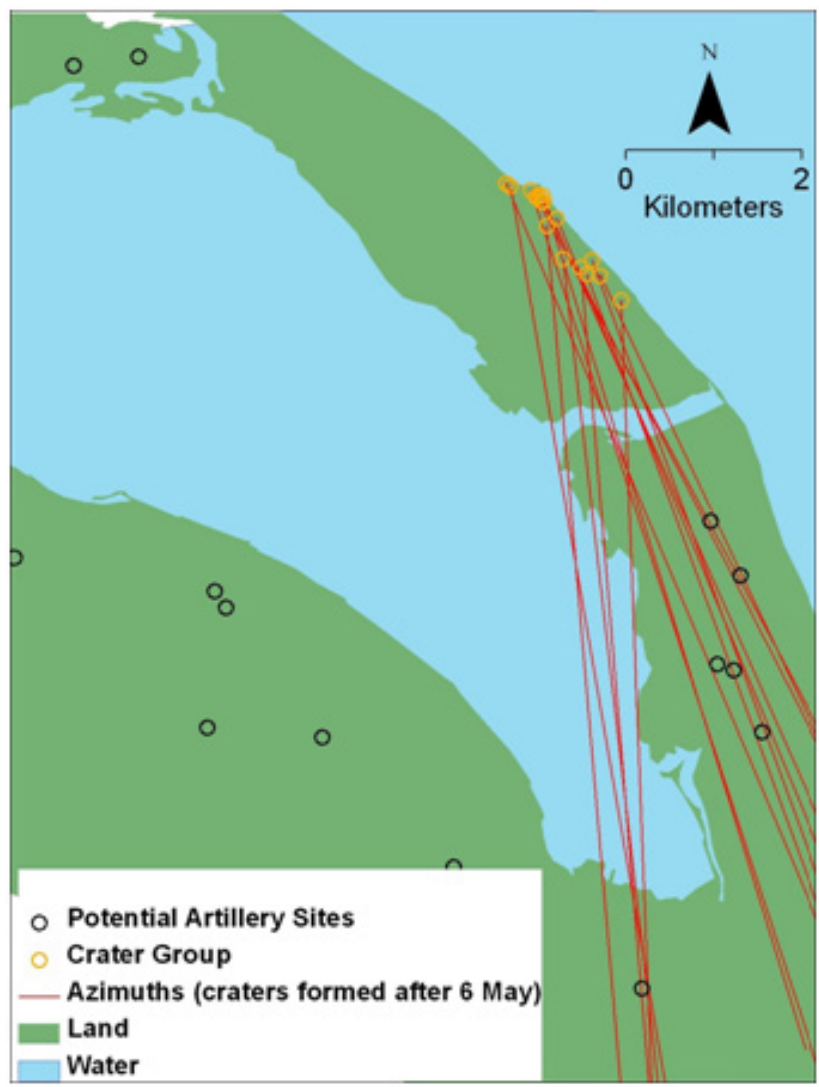

Figure 3. Graphic and analysis by AAAS, used with permission.

analysts at the American Association for the Advancement of Science (AAAS) were able to draw conclusions about the likely actor responsible for shelling, a fact that was repeatedly disputed by the parties to the conflict. ${ }^{44}$ Analysis of craters, their ejecta patterns, and likely trajectories of

\footnotetext{
${ }^{44}$ See, for example, an incident in January 2009: “The spokesman for the Sri Lankan military, Brig. V. U. B. Nanayakkara, denied that government artillery had hit a United Nations compound, or a hospital compound. He said that either the relief and hospital officials had been pressed by the rebels to disseminate false information, or that the Tamil Tigers had been responsible for the shelling." Quoted in Somini Senguptajan, "U.N. Staff and Hospital Come Under Shelling
} 
shells revealed that multiple impact craters stemmed from artillery positions of the Sri Lankan army. ${ }^{45}$

\section{Mobile Technology}

In addition to Syria, the armed conflict in north-east Nigeria is a prime example that demonstrates the impact camera enabled cell phones have on human rights fact-finding.

For two 2015 reports on violations by both Boko Haram and Nigerian security forces, Amnesty International analyzed close to 100 videos in addition to multiple photographs. The footagestemming from eyewitnesses and likely perpetrators, captured mainly on cell phones and shared via messaging apps or on social media, - played a crucial role in the research. The videos predominantly showed human rights violations by Nigerian military forces and an associated civilian militia, the so-called Civilian Joint Task Force (CJTF). A noteworthy lemon that slipped into this collection was a video of a likely homicide from outside the conflicted affected area. ${ }^{46}$

The videos captured multiple incidents related to the ongoing conflict. A single date-March 14, 2014-stood out both in terms of the severity and scale of violations and the amount of available digital content. On that day, Boko Haram attacked Giwa military barracks in Maiduguri, freeing hundreds of detainees. In response to the attack and prison break, Nigerian security forces and CJTF killed more than 600 men and boys, most of them recaptured detainees. ${ }^{47}$ Videographic evidence played a leading role in the following investigation. Footage included a Nigerian soldier executing an unarmed person in broad daylight who was lying on the ground. Two other videos showed how security forces and CJTF forced captured young male adults to dig graves before executing them by cutting their throats. (The same video showed up with claims that it originates in the Central African Republic).$^{48}$ While the location of this incident could not be independently verified from the footage alone, Amnesty International researchers were able to receive the original video files. This allowed analysts to confirm the incident date by reviewing the intact metadata of the files (which is often not possible since the metadata is normally altered or removed when files are shared through social media or mobile phone apps such as WhatsApp or Signal). Most importantly, the footage presented strong evidence in terms of agency, which is crucial to identify specific units or command responsibility. An inventory number visible on a rifle of a Nigerian soldier suggests that it belonged to the Support Company of the 81 Battalion (and Amnesty International researchers confirmed with sources within the military that this specific rifle has not been reported stolen). ${ }^{49}$ Such findings might have political or legal implications. The International Criminal Court is currently conducting a preliminary examination into the armed conflict in north-east Nigeria. Additionally, national legislation, such as the Leahy Law in the United States, prohibits military aid to foreign security forces that are implicated in serious violations of human rights. It is precisely this sort of detail on unit involvement and command responsibility that has serious implications on the vetting process of the Leahy Law..$^{50}$

Another example comes from Bama, $70 \mathrm{~km}$ east of Maiduguri, where several individuals recorded various incidents. Multiple videos showed how Boko Haram fighters in September 2014 took prisoners from Bama prison, tied them behind a truck, dragged them to a bridge, lined them up,

as Sri Lanka Fights Cornered Rebels," New York Times, January 27, 2009, accessed July 28, 2016, http://www.nytimes. com/2009/01/28/world/asia/28lanka.html? r=0.

${ }^{45}$ See especially Figure 11, American Association for the Advancement of Science "High-Resolution Satellite Imagery and the Conflict in Sri Lanka," (2009), accessed July 28, 2016, http://www.aaas.org/geotech/sri lanka 2009.

46 "Man arrested with dead baby in suitcase in Abuja," September 16, 2012, accessed July 28, 2016, http://naijagists.com/ man-arrested-with-dead-baby-stuffed-suitcase-in-abuja/.

${ }^{47}$ Amnesty International, “Nigeria: More than 1,500 killed in armed conflict in north-east Nigeria in early 2014," March 31, 2014, accessed July 28, 2016, https://www.amnesty.org/en/documents/AFR44/004/2014/en/.

48 "Génocide en Centrafrique: L'élimination des musulmans se poursuit paisiblement," Alwihda Info, June 3, 2014, http://www.alwihdainfo.com/Genocide-en-Centrafrique-L-elimination-des-musulmans-se-poursuit-paisiblement a11542.html. [Warning: Graphic Content]

${ }^{49}$ Amnesty International, “Nigeria: Gruesome footage implicates military in war crimes," August 5, 2014, accessed July 28, 2016, https://www.amnesty.org/en/latest/news/2014/08/nigeria-gruesome-footage-implicates-military-war-crimes/.

50 "Leahy Vetting," U.S. Department of State, accessed July 25, 2016, https://www.humanrights.gov/leahy-vetting.html. 


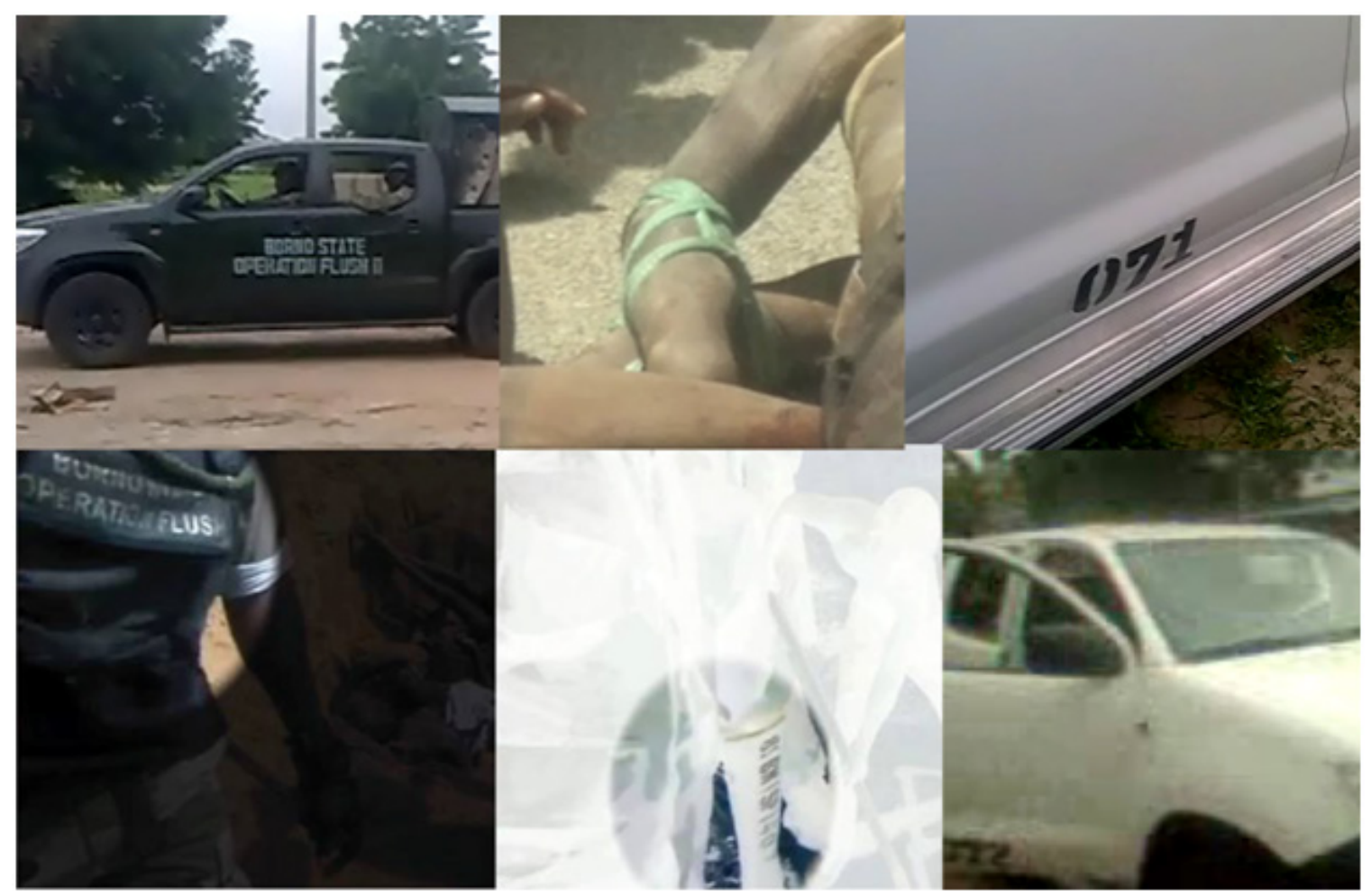

Figure 4. Some colors inverted using VLC Player, for enhancement purposes only. Graphic produced by author.

killed them, and threw their corpses in a river. Due to the clear geographic landmarks visible in the video (prison and bridge), it was possible to confirm the exact locations and reconstruct the event.

More than a year earlier, the Nigerian military conducted a screening operation of hundreds of men in the same town, after which 35 were arrested and later executed. Several, lengthy videos allowed analysts to reconstruct the operation, identifying the exact location as 380 meters east of Bama market. At one point, eyewitnesses were filming each other. Such multi-angle videos will play an increasingly important role in human rights investigations, as they allow for detailed crime scene reconstructions, especially when combined with satellite imagery, as is already common in law enforcement investigations. Examples for such an approach are Situ Research's, Forensic Architecture's and Human Rights Watch's reconstruction of White Phosphorous attacks on residential areas in Gaza in 2009, ${ }^{51}$ or Forensic Architecture's and Amnesty International's investigation into the attack on Rafah on August 1, 2014. ${ }^{52}$

Describing the amount of human rights relevant photo and videographic evidence from Syria goes beyond the scope of this article, but also raises important questions about archiving and evidence handling. Jay Aronson in his contribution to this special issue provides an analysis on preservation of human rights related video, in which he identifies two core tensions: first, the purpose of preservation; and second, the control over the saved content. Many important questions around consent, security, privacy, and ethics can be traced back to these two issues, as Jay Aronson argues in his article published in this special issue. ${ }^{53}$ The Syria Justice and Accountability Center ${ }^{54}$,

\footnotetext{
51 “White Phosphorus Report," Situ Research, accessed July 25, 2016, http://www.situresearch.com/works/whitephosphorus-report.

52 “'Black Friday': Carnage in Rafah," Amnesty International, accessed July 25, 2016, https://blackfriday.amnesty.org/.

${ }^{53}$ Jay Aronson, “Preserving Human Rights Media," Genocide Studies and Prevention: An International Journal 11, no. 1 (2017): 82-99.

${ }^{54}$ U.S. Department of State, “The Syria Justice \& Accountability Center. Fact Sheet," February 20, 2013, accessed July 29 , 2016, http://www.state.gov/r/pa/prs/ps/2013/02/205031.htm.
} 
as a newly created organization, has been tasked with this effort, among other responsibilities. Automated analysis will play an increasingly important role in processing large datasets for human rights research and event reconstruction. For example, Carnegie Mellon University's Center for Human Rights Science assisted with investigating the killing of protestors in Ukraine by processing 520 videos with a total length of 65 hours with an audio analysis and synchronization tool. ${ }^{55}$

To give a final example of the increasing evidentiary value of video, digital content is playing an increasingly important role in assessing the legality or proportionality of airstrikes by international forces. Videos of suspected Russian airstrikes have been used to identify specific strike locations in residential areas, as analysts can use videos and photographs to geolocate specific buildings that were destroyed by airstrikes. For example, 17 civilians, including three children, were killed and at least 34 civilians were injured in September 2015 in Talbisseh, when suspected Russian air strikes hit Karama Street in the center of the city. ${ }^{56}$ Similarly, multiple buildings in a residential neighborhood in the immediate vicinity of a mosque were flattened in one of the first US led coalition airstrikes, on Kafr Deryan, in September 2014. While this information alone does not answer the question if this was a legitimate military target, the fact that videos show what appear to be multiple civilian victims, including children, ${ }^{57}$ would suggest otherwise, and raises questions for military commanders about violations of IHL. Additionally, Human Rights Watch identified the missile remnants visible in a photograph circulated online as the turbofan engine of a U.S. Tomahawk missile, ${ }^{58}$ tying the airstrikes in the area to US forces. This assessment is further supported by YouTube videos released by the U.S. Navy showing the launch of cruise missiles on the day of the attack..$^{99}$

As the above examples have demonstrated, cell phones have become important tools to collect and subsequently transmit digital audiovisual content that can provide important facts about the date and location of an incident. However, they go beyond providing such basic facts and often present crime base or linkage evidence, which reveal violations that would have gone otherwise unnoticed, and in the best case scenario identify the responsible actor. Tapping into this potential for reducing information uncertainty can provide the necessary facts and evidence to counter perpetrator strategies of denial and minimization.

As the final case study will demonstrate in detail, combining satellite imagery with citizen media can increasingly strengthen mass atrocity research.

\section{The Convergence of ICTs to Lead Atrocity Research}

There has been a notable shift since human rights groups started using remote sensing in the early 2000s as citizen media can gradually guide satellite imagery analysis. Such a tip and cue process was not possible before the widespread proliferation of camera-enabled cell phones. Research into suspected mass graves in Burundi provides a good case study of new ICT-led workflows in human rights crisis research.

In December 2015, reports about mass graves emerged shortly after Burundian security forces killed dozens of people on December 11, 2015. The killings included well-documented incidents of extrajudicial killings with evidence of close range shots to the head of some victims and at least

${ }^{55}$ Junwei Liang, et al, “Video Synchronization and Sound Search for Human Rights Documentation and Conflict Monitoring," Center for Human Rights Science Report, (June 2016), accessed July 25, 2016, http://www.cmu.edu/chrs/ documents/Video-Synchronization-Technical-Report.pdf.

${ }^{56}$ Amnesty International: Syria, “'Civilian objects were not damaged': Russia's statements on its attacks in Syria unmasked," December 23, 2015, accessed July 29, 2016, https://www.amnesty.org/en/documents/mde24/3113/2015/en/.

${ }^{57}$ Christoph Koettl, "Dissecting a US Airstrike in Syria," October 26, 2016, accessed March 17, 2017, https://medium. com/lemming-cliff/dissecting-a-us-airstrike-in-syria-9c6e31b12fff\#.4wy2yz5f2.

${ }^{58}$ Human Rights Watch, “US/Syria: Investigate Possible Unlawful US Strikes. At Least 7 Civilians Dead; Residents Say No Evident Military Target," September 27, 2014, accessed July 29, 2016, https://www.hrw.org/news/2014/09/27/us/syriainvestigate-possible-unlawful-us-strikes.

${ }^{59}$ U.S. Navy, “USS Arleigh Burke launches Tomahawk Land Attack Missiles to combat ISIL," September 23, 2014, accessed July 29, 2016, https://www.youtube.com/watch?v=H9034BawdX4; "USS Philippine Sea launches Tomahawk Land Attack Missiles to combat ISIL," September 23, 2014, accessed July 29, 2016, https://www.youtube.com/watch?v=6ad67l]fdk. 
one body tied up. However, the question of what happened to the bodies remained unanswered for several weeks after the incident. By January 2016, images started to appear on social media that claimed to show mass graves.

A shaky cell phone video of a desolated area was shared with Amnesty International. The short video did not reveal many reference points and ended with showing a small area of disturbed earth. A slow motion review of the video allowed analysts to extract crucial details: First, the video appeared to show five separate, small mounds. Second, the video included at least some geographic reference points, most notably an abandoned building, grave stones, and palm trees. Field and news reports suggested that one possible mass burial site was near Mpanda cemetery, to the north of the capital Bujumbura. A review of pre-event satellite imagery on Google Earth and other geographic databases eventually allowed pinpointing the exact location of the likely gravesite. Equipped with this new information extracted from the video and Google Earth, Amnesty International was able to commission analysis of new satellite imagery (Google Earth imagery normally does not provide the most current imagery. In this case, the available imagery was from prior to the event of interest).

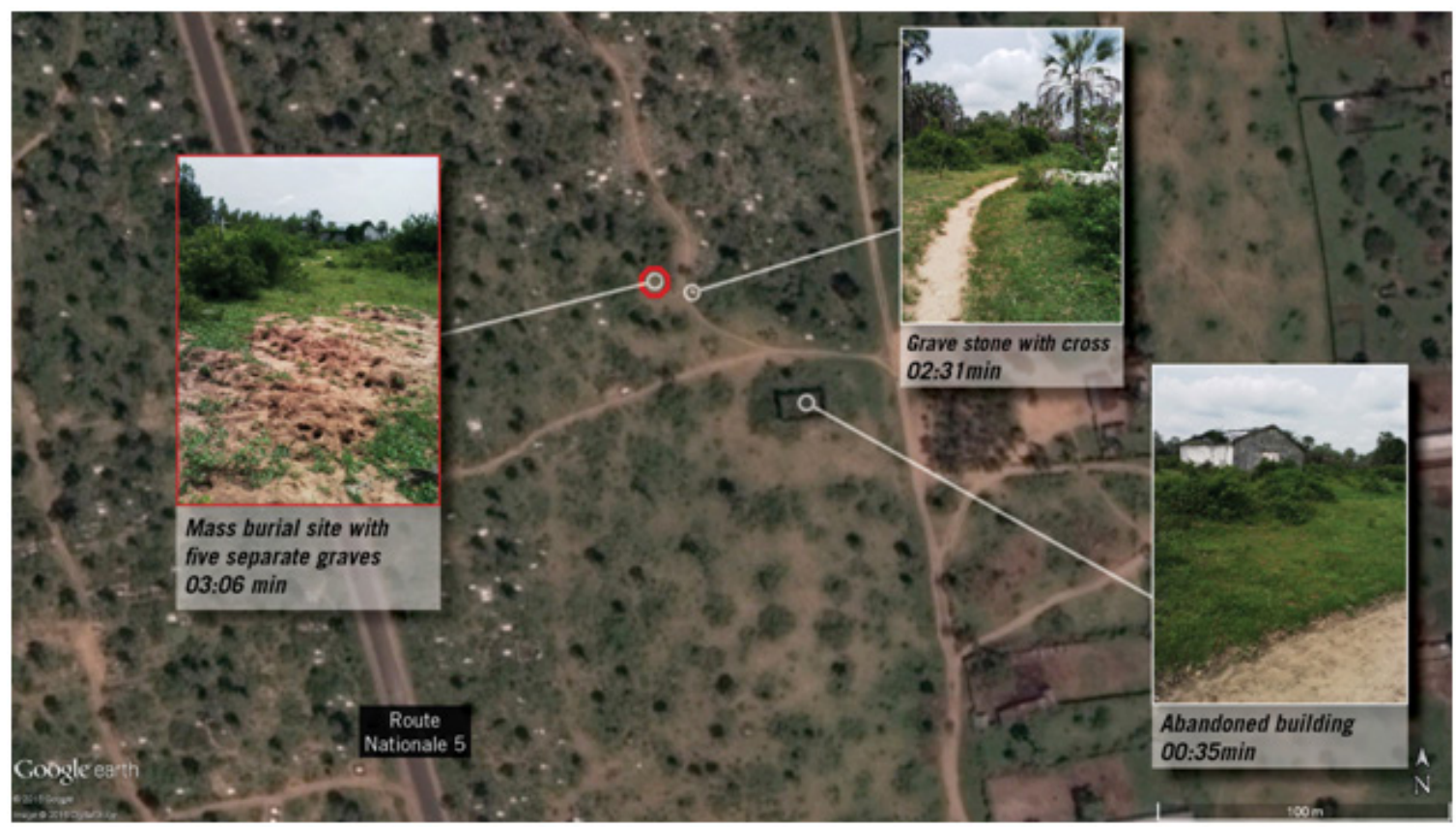

Figure 5. @ DigitalGlobe/Google Earth. November 3, 2015. Graphic produced by author.

The analysis of new satellite imagery provided further important details. A time series of images showed that the area of disturbed earth emerged between 3 November and 22 December 2015. Another satellite image from early January 2016 showed light vegetation re-growth, suggesting that the earth disturbance visible in the December image was likely very fresh, thus being consistent with the eyewitness claims that it is a mass burial site containing bodies of some of those killed on 11 December.

This case study describes the successful deployment of a combination of ICTs to detect a likely mass atrocity crime and led to the publication of a briefing that would have been impossible without the use of ICTs. ${ }^{60}$ Specifically, combining multiple technologies allowed the following:

${ }^{60}$ Amnesty International, "Burundi: Suspected mass graves of victims of 11 December violence," January 29, 2016, accessed July 30, 2016, https://www.amnesty.org/en/documents/afr16/3337/2016/en/; Please note that a briefing on the killings, published in the immediate aftermath of the events, was based on field research: "My children are scared': Burundi's deepening human rights crisis," December 22, 2015, accessed July 30, 2016, https://www.amnesty.org/en/ documents/afr16/3116/2015/en/. 
1. Gaining access to a restricted area: Both video and satellite imagery allowed to gain remote access to a suspected mass grave site, which at that point was restricted to international, independent fact-finders.

2. Determining the exact location: The video, despite being of low quality and lacking any major landmarks or reference points, allowed establishing the exact location of the suspected mass burial site.

3. Determining the time frame: Commercially available satellite imagery confirmed the exact location of the site. Most importantly, however, the time series of satellite imagery allowed establishing a time window within which the suspected grave site was created.

Finally, it is important to stress that ICTs, by themselves, did not reveal all details about this incident. Both the video and satellite images showed disturbed earth at a specific location, created in a specific time-window, but this did not necessarily prove the existence of a mass grave, nor what was below the disturbed earth. ${ }^{61}$ Building on traditional research (eyewitnesses testimony), however, this technology-enabled research helped build a strong case, which allowed calls for accountability and further investigations, including physical access to the site to conduct forensic analysis. Thus, the analysis strongly reduced the uncertainties surrounding multiple reports of mass graves that were circulating for weeks in the aftermath of the extrajudicial executions.

\section{Teaching the Next Generation}

When teaching the next generation of human rights researchers, it is imperative to not solely transfer technical skills. No matter which technology is used, at the core should be the responsible use of data, which is defined as

[t]he duty to ensure people's rights to consent, privacy, security and ownership around the information processes of collection, analysis, storage, presentation and reuse of data, while respecting the values of transparency and openness. ${ }^{62}$

Beyond this core guiding principle, different technologies create different risk scenarios, which should be considered at the onset of any new research project. Especially the increase of audiovisual materials through cell-phone cameras leads to datasets whose content often include information that can be used to identify specific individuals, a challenge that will only be exacerbated by the increased use of UAVs. In addition to the content, metadata that is invisible embedded in photographs or videos can reveal sensitive information about a person.

Satellite imagery that reveals little to no information about specific individuals, however, creates other risk factors. These include providing intelligence to a party to a conflict, or the public dissemination of other sensitive information such as trapped civilians who are fleeing violence. Only the responsible use of data (based on well-established professional standards) generated from inherent surveillance technologies such as satellites and drones can solve the tension of its use by human rights groups, who at the same time criticize the increase in government mass surveillance.

More and more resources exist that can be used in teaching on these topics. They include a growing body of academic articles on remote sensing, ${ }^{63}$ in addition to more technical resources

${ }^{61}$ However, for research on grave detection from air- or space-borne sensors, see G. Leblanc, M. Kalacska, and R. Soffer, "Detection of single graves by airborne hyperspectral imaging," Forensic Science International, Volume 245 (2014), 17- 23; Hannah Hoag, "Using Technology to Find Hidden Graves," Discover, (October 2015,) accessed July 30, 2016, http://discovermagazine.com/2015/oct/14-body-of-evidence; M. Kalacska, et al, "The Application of Remote Sensing for Detecting Mass Graves: An Experimental Animal Case Study from Costa Rica," Journal of Forensic Sciences, 54 (2009), 159-166.

62 “DatNav: How to navigate and integrate digital data in human rights research," (August 2016), accessed September 2015, https://www.theengineroom.org/wp-content/uploads/2016/09/datnav.pdf, 63.

${ }^{63}$ See, for example, Susan Wolfinbarger, "Remote Sensing as a Tool for Human Rights Fact-Finding," in The Transformation of Human Rights Fact-Finding, ed. Philip Alston and Sarah Knuckey, (Oxford: Oxford University Press, 2015), 463478; Steven Livingston, "Commercial Remote Sensing Satellites and the Regulation of Violence in Areas of Limited Statehood," CGCS Occasional Paper Series on ICTs, Statebuilding, and Peacebuilding in Africa, Nr. 5, (January 2015), 
produced by universities. ${ }^{64}$ Initial in-depth writings have been published in the area of open source research and verification ${ }^{65}$ and the use of mobile technology ${ }^{66}$, in addition to the sharing of best practices, hands-on guides, ${ }^{67}$ case studies $^{68}$ and ethics. ${ }^{69}$

What is still missing is the development of actual curricula on new methodologies in human rights research, although first academic programs in this field are emerging. ${ }^{70}$ Additionally, large human rights groups have developed multi-day trainings for both internal and external audiences focusing exclusively on the ethical and impactful use of new technologies in human rights research.

Finally, there are increasing opportunities for students to gain practical experience in this work, through, for example, the Syracuse University's Syrian Accountability Project ${ }^{71}$ or the Digital Verification Corps, a partnership between Amnesty International and the Universities of Berkeley, Essex, Toronto and Pretoria.

\section{Conclusion and Outlook}

Due to the high level of information uncertainty during human rights crises, there is a very high premium on fact-finding and the collection of reliable evidence. As this paper has shown, certain ICTs can help achieve this goal and can contribute meaningfully to mass atrocities research by reducing uncertainties. Often, this comes through the collection and transmission of highly relevant details on specific violations, including crime base and linkage evidence. To be clear, the technologies described here are most impactful if they are part of a holistic approach to crisis research: integrated into traditional research and deployed to address specific information gaps, instead of relying on a single technology or source.

There are a number of steps the human rights community can take to increase the efficiency of its current use of ICTs. First, human rights organizations can provide more trainings to their research staff. For example, Amnesty International has started to integrate geospatial and open source research and verification into its core research methodology training. While this is an important step, more can be done. Resources on methodology in these areas are still insufficient and there are needs and opportunities that can be addressed outside the practitioners' field. Academics could contribute to the development of guidelines on the use of ICTs based on well-established and proven human rights research methodologies. Funders can support projects that go beyond tool development, such as grants for curricula development, in order to provide the next generation of researchers with the appropriate coursework.

Finally, human rights groups largely work in silos when it comes to filtering out misinformation from relevant content. While human rights crisis reporting increasingly builds on digital content and technology enabled research, the misinformation that was encountered during the research process largely remains on the computers or in the individual memory of a researcher. As a lot of digital misinformation is recycled content that re-emerges during crises, knowledge sharing and

accessed September 15, 2016, http://www.global.asc.upenn.edu/app/uploads/2015/01/Livingston Final.pdf.

${ }^{64}$ See, for example, "The Nature of Geographic Information. An Open Geospatial Textbook," accessed September 15, 2015, https://www.e-education.psu.edu/natureofgeoinfo/.

${ }^{65}$ Koettl, Citizen Media Research and Verification.

${ }^{66}$ Jay Aronson, "Mobile phones, social media and big data in human rights fact-finding. Possibilities, challenges, and limitations," in The Transformation of Human Rights Fact-Finding, eds. Philip Alston and Sarah Knuckey, (Oxford: Oxford University Press, 2015), 441-461.

67 "Citizen Evidence Lab," Amnesty International, accessed September 15, 2016, https://citizenevidence.org/.

${ }^{68}$ Christoph Koettl: "Using UGC in human rights and war crimes investigations," in Verification Handbook for investigative reporting, ed. Craig Silverman, (Maastricht: EJC, 2015), Chapter 7, accessed September 15, 2015, http://verificationhandbook.com/book2/chapter7.php.

${ }^{69}$ On the topic of crowdsourcing, which has not been addressed in this article, see Martin Shields, "The Technologist's Dilemma. Ethical Challenges of Using Crowdsourcing Technology in Conflict and Disaster-Affected Regions," in Georgetown Journal of International Affairs Vol. 14, No. 2 (Summer/Fall 2013), 157-163.

${ }^{70}$ See, for example, the University of Essex's focus on technology and human rights in its 2015 Summer School, accessed September 15, 2016, https://www.essex.ac.uk/hrc/summerschool/default.aspx.

71 "Syria Accountability Project", Syracuse University College of Law, accessed September 15, 2016, http://syrianaccountabilityproject.org/. 
the creation of community knowledge, in the form of a shared database, could further help address the lemon problem.

\section{Bibliography}

Amnesty International. “'Shocking' Video Shows Armed Group Carrying Out Summary Killings of Men in Syria's Idlib Province, Says Amnesty International." November 1, 2012. Accessed July 25, 2016, http://www.amnestyusa.org/news/press-releases/shocking-video-showsarmed-group-carrying-out-summary-killings-of-men-in-syria-s-idlib-province-says.

"North Korea: New images show blurring of prison camps and villages." March 7, 2013. Accessed July 27, 2016. https://www.amnesty.org/en/latest/news/2013/03/north-koreanew-images-show-blurring-prison-camps-and-villages/.

-------. "New satellite images show scale of North Korea's repressive prison camps." December 5, 2013. Accessed July 27, 2016. https://www.amnesty.org/en/latest/news/2013/12/newsatellite-images-show-scale-north-korea-s-repressive-prison-camps/.

-------- "Nigeria: More than 1,500 killed in armed conflict in north-east Nigeria in early 2014." March 31, 2014. Accessed July 28, 2016. https://www.amnesty.org/en/documents/ AFR44/004/2014/en/.

------. "Nigeria: Gruesome footage implicates military in war crimes." August 5, 2014. Accessed July 28, 2016. https://www.amnesty.org/en/latest/news/2014/08/nigeria-gruesome-footageimplicates-military-war-crimes/.

------. Syria, " 'Civilian objects were not damaged': Russia's statements on its attacks in Syria unmasked." December 23, 2015. Accessed July 29, 2016. https://www.amnesty.org/en/ documents/mde24/3113/2015/en/.

-------. "Burundi: Suspected mass graves of victims of 11 December violence." January 29, 2016. Accessed July 30, 2016. https://www.amnesty.org/en/documents/afr16/3337/2016/en/.

-------. "'My children are scared': Burundi's deepening human rights crisis." December 22, 2015. Accessed July 30, 2016. https://www.amnesty.org/en/documents/afr16/3116/2015/en/.

------.. “'Black Friday': Carnage in Rafah.” Accessed July 25, 2016. https://blackfriday.amnesty.org/. -------. “Citizen Evidence Lab”. Accessed September 15, 2016. https://citizenevidence.org/.

American Association for the Advancement of Science. "High-Resolution Satellite Imagery and the Conflict in Sri Lanka." (2009) Accessed July 28, 2016. http://www.aaas.org/geotech/ sri lanka 2009.

------. "Documentation of Petrochemical Release: Bodo, Nigeria." Accessed July 26, 2016. http://www.aaas.org/page/documentation-petrochemical-release-bodo-nigeria.

Akerlof, George. “The Market for 'Lemons': Quality Uncertainty and the Market Mechanism." The Quarterly Journal of Economics 84, 3 (Aug 1970): 488-500. https://doi.org/10.2307/1879431

Aronson, Jay D. "Mobile phones, social media and big data in human rights fact-finding. Possibilities, challenges, and limitations." In The Transformation of Human Rights FactFinding, edited by Philip Alston and Sarah Knuckey, 441-461. Oxford: Oxford University Press, 2015.

-------. "Preserving Human Rights Media." Genocide Studies and Prevention: An International Journal 11, no. 1 (2017): 82-99. http://doi.org/10.5038/1911-9933.11.1.1441

Bermudez, Joseph S. Jr., Andy Dinville, and Mike Eley. "North Korea: Ch'oma-bong Restricted Area." March 17, 2016. Accessed July 27, 2016. https://www.hrnk.org/uploads/pdfs/ASA HRNK Chmbg 201603 FINAL.pdf.

Bowcott, Owen. "eyeWitness to Atrocities: the app aimed at bringing war criminals to justice." The Guardian, June 7, 2015. Accessed July 25, 2016, https://www.theguardian.com/ technology/2015/jun/08/eyewitness-to-atrocities-the-app-aimed-at-bringing-warcriminals-to-justice.

Bromley, Lars. "Relating violence to MODIS fire detections in Darfur, Sudan." International Journal of Remote Sensing, 31, 9 (2010): 2277-2202. Accessed July 29, 2016. https://doi. org $/ 10.1080 / 01431160902953909$

DatNav: How to navigate and integrate digital data in human rights research. (June 2016). Accessed July 25, 2016, https://www.theengineroom.org/wp-content/uploads/2016/09/datnav.pdf. 
Dubberley, Sam. "New data and the importance of collaboration." July 18, 2016. Accessed July 28, 2016. https://citizenevidence.org/2016/07/18/new-data-and-the-importance-ofcollaboration/.

Edwards, Scott. "Fieldwork from the Sky: Remote Data Collection from War Zones." International Sudan Studies Association 2009 annual conference in Pretoria (2009), South Africa.

Google. "Terra Bella." Accessed March 17, 2017. https://terrabella.google.com/.

Hamilton, Chris. "Houla massacre picture mistake." BBC, May 29 2012. Accessed July 25, 2016. http://www.bbc.co.uk/blogs/theeditors/2012/05/houla massacre picture mistake.html.

Hawk, David. “The Hidden Gulag. Exposing North Korea's Prison Camps. Prisoners' Testimonies and Satellite Photographs. 2003." US Committee for Human Rights in North Korea, 2003. Accessed July 27, 2016. https://www.hrnk.org/uploads/pdfs/NKHiddenGulag DavidHawk.pdf.

Hoag, Hannah. "Using Technology to Find Hidden Graves.” Discover, October 2015. Accessed July 30, 2016. http://discovermagazine.com/2015/oct/14-body-of-evidence.

Humanity United. "The Tech Challenge for Atrocity Prevention." Accessed July 20, 2016. http:// thetechchallenge.org/blog/.

Human Rights Center, School of Law, University of Berkeley. "Beyond Reasonable Doubt. Using scientific evidence to advance prosecutions at the International Criminal Court." Workshop report. Accessed July 30, 2016. https://www.law.berkeley.edu/files/HRC/HRC Beyond Reasonable Doubt FINAL.pdf.

Human Rights Watch. "Sri Lanka: Execution Video Shows Need for International Inquiry." August 26, 2009. Accessed July 27, 2016. http://www.hrw.org/news/2009/08/26/sri-lanka-executionvideo-shows-need-international-inquiry.

--------. “US/Syria: Investigate Possible Unlawful US Strikes. At Least 7 Civilians Dead; Residents Say No Evident Military Target." September 27, 2014. Accessed July 29, 2016. https://www. hrw.org/news/2014/09/27/us/syria-investigate-possible-unlawful-us-strikes.

Institute of International Studies, University of California Berkeley. "Robert Keohane Interview: Conversations with History", March 9, 2004. Accessed July 27, 2016. http://globetrotter. berkeley.edu/people4/Keohane/keohane-con0.html.

Kalacska, M. E., L.S. Bell, G. Arturo Sanchez-Azofeifa, and T. Caelli. "The Application of Remote Sensing for Detecting Mass Graves: An Experimental Animal Case Study from Costa Rica." Journal of Forensic Sciences, 54 (2009): 159-166. https://doi.org/10.1111/j.15564029.2008.00938.x

Keohane, Robert O. After Hegemony: Cooperation and Discord in the World Political Economy. Princeton: Princeton University Press, 1984.

Koettl, Christoph. “\#DemandJustice: The Website War Criminals Don't Want You To Share.” July 19, 2012. Accessed July 27, 2016. http://blog.amnestyusa.org/africa/demandjustice-thewebsite-war-criminals-dont-want-you-to-share/.

------. "Using UGC in human rights and war crimes investigations". In Verification Handbook for investigative reporting, ed. Craig Silverman, Chapter 7. Maastricht: EJC, 2015.

--------. "Citizen Media Research and Verification: An Analytical Framework for Human Rights Practitioners." Human Rights in the Digital Age: CGHR Practitioner Paper 1, Cambridge, UK: University of Cambridge Centre of Governance and Human Rights, (January 2016). Accessed July 27, 2016. http://www.cghr.polis.cam.ac.uk/publications/cghr-practitionerpapers-series/paper-1.

-------. "Dissecting a US Airstrike in Syria." October 26, 2016. Accessed March 17, 2017. https:// medium.com/lemming-cliff/dissecting-a-us-airstrike-in-syria-9c6e31b12fff\#.4wy2yz5f2.

Leblanc, G., M. Kalacska, and R. Soffer. "Detection of single graves by airborne hyperspectral imaging." Forensic Science International, Volume 245 (2014), 17-23. https://doi.org/10.1016/j. forsciint.2014.08.020

Liang, Junwei, Susanne Burger, Alex Hauptmann, and Jay D. Aronson. "Video Synchronization and Sound Search for Human Rights Documentation and Conflict Monitoring." Center for Human Rights Science Report, (June 2016). Accessed July 27, 2016. http://www.cmu.edu/ chrs/documents/Video-Synchronization-Technical-Report.pdf 
Little, Mark. "The Human Algorithm," May 20, 2011. Accessed July 27, 2016. http://blog.storyful. com/2011/05/20/the-human-algorithm-2.

Livingston, Steven. "Commercial Remote Sensing Satellites and the Regulation of Violence in Areas of Limited Statehood." CGCS Occasional Paper Series on ICTs, Statebuilding, and Peacebuilding in Africa, Nr. 5, (January 2015). Accessed July 27, 2016. http://www.global. asc.upenn.edu/app/uploads/2015/01/Livingston Final.pdf.

Naimer, Karin, Widney Brown, and Ranit Mishori. "MediCapt in the Democratic Republic of the Congo: The Design, Development, and Deployment of Mobile Technology to Document Forensic Evidence of Sexual Violence." Genocide Studies and Prevention: An International Journal 11, no. 1 (2017): 25-35.

Office of the UN High Commissioner for Human Rights, United Nations. Technical Note prepared by the Special Rapporteur on extrajudicial, summary or arbitrary executions, Mr. Philip Alston, in relation to the authenticity of the "Channel 4 videotape." January 7, 2010. Accessed July 27, 2016. http://groundviews.org/wp-content/uploads/2011/05/un technical note.pdf?x98647.

-------. "North Korea: UN Commission documents wide-ranging and ongoing crimes against humanity, urges referral to ICC," February 17, 2014. Accessed July 27, 2016. http://www. ohchr.org/EN/NewsEvents/Pages/DisplayNews.aspx?NewsID=14255\&LangID=E\#sthash. ukBW9bLP.dpuf.

-------. "Satellite images of currently existing political prison camps (kwanliso) in the Democratic People's Republic of Korea." January 28 2014. Accessed July 27, 2014. http://www.ohchr. org/EN/HRBodies/HRC/CoIDPRK/Pages/ReportoftheCommissionofInquiryDPRK.aspx.

Orentlicher, Diane. "Bearing witness: The art and science of human rights fact-finding." Harvard Human Rights Journal 3 (1990): 83-135.

Pain, Julien. "Beware of internet misinformation: hoax footage of atrocities in Ivory Coast." France 24, July 4, 2011. Accessed July 27, 2016. http://observers.france24.com/en/20110407-bewareinternet-misinformation-hoax-footage-atrocities-ivory-coast.

PBS Newshour. "A new generation of human rights investigators turns to high-tech methods." February 13, 2017. Accessed February 27, 2017. https://www.youtube.com/ watch? $\mathrm{v}=\mathrm{dDLtL} 8 \mathrm{aWRAQ}$.

Raymond, Nathaniel A., Brittany L. Card, and Isaac L. Baker. "A New Forensics: Developing Standard Remote Sensing Methodologies to Detect and Document Mass Atrocities." Genocide Studies and Prevention: An International Journal, Volume 8, Issue 3, (2013) Article 6. Accessed July 26, 2016. http://scholarcommons.usf.edu/cgi/viewcontent.cgi?article=1031\&context=gsp.

Reuters, Video Shows Harsh Life in N. Korean Camp - Japan TV, February 27, 2004. Accessed March 17, 2017. http://www.washingtonpost.com/wp-dyn/articles/A11548-2004Feb27.html.

"Rodney King beating video, full length footage." YouTube video, 8:08. March 3, 1991. Accessed July 25, 2016. https://www.youtube.com/watch? $\mathrm{v}=\mathrm{sb} 1$ WywIpUtY.

Spada, Andrea. Twitter Post. March 1, 2016, 6:43a.m. https://twitter.com/Baldoriano/ status/704633182063370240.

Senguptajan, Somini. “U.N. Staff and Hospital Come Under Shelling as Sri Lanka Fights Cornered Rebels." New York Times, January 27, 2009. Accessed July 28, 2016. http://www.nytimes. com/2009/01/28/world/asia/28lanka.html? $\mathrm{r}=0$.

Shields, Martin. "The Technologist's Dilemma. Ethical Challenges of Using Crowdsourcing Technology in Conflict and Disaster-Affected Regions." Georgetown Journal of International Affairs Volume Vol. 14, No. 2 (Summer/Fall 2013), 157-163.

Situ Research. "White Phosphorus Report." Accessed July 25, 2016. http://www.situresearch.com/ works/white-phosphorus-report.

Shoichet, Catherine E. and Madison Park. "North Korean prison camp survivor admits inaccuracies, author says." CNN, January 20, 2015. Accessed July 27, 2016. http://www. cnn.com/2015/01/18/asia/north-korea-defector-changes-story/.

Silverman, Craig. "Lies, Damn Lies, and Viral Content. How news websites spread (and debunk) online rumors, unverified claims, and misinformation." Tow Center for Digital Journalism, February 10, 2015. Accessed July 30, 2016. http://towcenter.org/research/lies-damn-liesand-viral-content/. 
Syracuse University College of Law. "Syria Accountability Project." Accessed September 15, 2016. http://syrianaccountabilityproject.org/.

Taft, Sally. "How did you help us change the way we report the news?" December 27, 2014. Accessed July 28, 2016. http://www.bbc.com/news/world-30421631.

United Nations. Report of the Special Rapporteur on extrajudicial, summary or arbitrary executions, Christof Heyns: Use of information and communications technologies to secure the right to life, April 24, 2015. A/HRC/29/37.

U.S. Department of State. “Leahy Vetting." Accessed July 25, 2016. https://www.humanrights.gov/ leahy-vetting.html

Wolfinbarger, Susan. "Remote Sensing as a Tool for Human Rights Fact-Finding." In The Transformation of Human Rights Fact-Finding, edited by Philip Alston and Sarah Knuckey, 463-478. Oxford: Oxford University Press, 2015.

"Zoran Petrovic video." YouTube video, 1:16. July 14, 1995. Accessed July 25, 2016. https://www. youtube.com/watch?v=344e D-Vc7g. 